\title{
Pengaruh Faktor Individu, Organisasi dan Lingkungan Kerja Terhadap Stres Kerja Auditor (Studi Empiris Pada Auditor Pemerintah di Sulawesi Utara)
}

\section{HENDRA YANTO HONGKONG ${ }^{1}$, LINTJE KALANGI ${ }^{2}$, HENDRIK GAMALIEL ${ }^{3}$}

\author{
1,2,3Program Studi Magister Akuntansi Fakultas Ekonomi dan Bisnis Universitas Sam Ratulangi \\ email: hendrahongkong@gmail.com, lintje_kalangi@yahoo.com,hendrik_gamaliel@unsrat.ac.id
}

\begin{abstract}
This study aims to examine empirically the influence of individual, organizational and work environment factors on the work stress of existing government auditors in North Sulawesi. This is a quantitative study and primary data were used in this study. Data were collected by questionnaires and measured by Likert scales. They were distributed to the internal auditors of the government in 7 (seven) inspectorate offices in North Sulawesi. The results show that the individual factors, described as role conflict, role ambiguity, time pressure and excessive workload, do not influence the work stress of the government's internal auditor. Organizational factors, described as reward indicators, participation in decision making and leadership style, do not influence the work stress of the internal auditor of the government. Work environment factors, such as cleanliness, lighting, noise, temperature, and air circulation, do not influence the work stress of government auditors.
\end{abstract}

Keywords: stress, auditor, inspectorate

\begin{abstract}
Abstrak. Penelitian ini bertujuan untuk membuktikan secara empiris pengaruh faktor individu, organisasi dan lingkungan kerja terhadap stres kerja auditor pemerintah yang ada di Sulawesi Utara. Metode yang digunakan pada penelitian ini adalah metode penelitian kuantitatif dengan sumber data primer. Teknik pengumpulan data dilakukan dengan menggunakan kuisioner yang dibagikan kepada auditor internal pemerintah di 7 (tujuh) kantor inspektorat yang ada di Sulawesi Utara yang diukur dengan skala Likert. Hasil penelitian menunjukan bahwa faktor individu yang dijabarkan dengan indikator konflik peran, ambiguitas peran, tekanan waktu dan beban kerja berlebih tidak berpengaruh terhadap stres kerja auditor internal pemerintah. Faktor organisasi yang dijabarkan dengan indikator reward, partisipasi dalam pengambilan keputusan dan gaya kepemimpinan tidak berpengaruh terhadap stres kerja auditor internal pemerintah. Faktor lingkungan kerja seperti kebersihan, pencahayaan, kebisingan, suhu, dan sirkulasi udara tidak berpengaruh terhadap stres kerja auditor pemerintah.
\end{abstract}

Kata kunci: stres, auditor, inspektorat.

\section{Pendahuluan}

Dalam rangka menunjang program strategis pemerintah untuk mencapai tujuan pembangunan nasional, pembangunan infrastruktur terus dilakukan oleh pemerintah hal ini terlihat jelas didalam anggaran belanja negara tahun 2020 yang direncanakan mencapai 2.528 triliun Rupiah yang terdiri dari belanja pemerintah pusat sebesar 66 persen dan transfer ke daerah sebesar 34 persen. Komitmen Pemerintah untuk mempercepat pembangunan di daerah ditunjukkan dengan alokasi anggaran transfer ke daerah dan dana desa sebesar 858,8 triliun Rupiah atau meningkat 5,4 persen dari anggaran sebelumnya. Peningkatan alokasi tersebut akan diiringi dengan peningkatan kualitas implementasinya. Tujuannya agar belanja pemerintah daerah semakin efektif dan efisien dalam rangka meningkatkan layanan dasar publik, mendorong pertumbuhan ekonomi daerah, serta mengurangi kesenjangan dan kemiskinan. Dalam ikhtisar hasil pemeriksaan semester II tahun 2018 oleh Badan Pemeriksa Keuangan ditemukan sebanyak 6.076 permasalahan, 20 persen permasalahan pada kelemahan sistem pengendalian internal (SPI), 35 persen permasalahan ketidakpatuhan terhadap peraturan perundang-undangan dan 45 persen permasalahan ketidakhematan, ketidakefisienan dan ketidakefektifan yang kesemuanya menimbulkan potensi kerugian dan kerugian negara yang sangat besar. 
Dalam upaya mendukung keberhasilan penyelenggaraan pemerintahan, keuangan negara wajib dikelola secara tertib, taat aturan perundang-undangan, efisien, ekonomis, efektif, transparan dan bertanggungjawab. Pertanggungjawaban atas penggunaan dana dalam penyelenggaraan pemerintahan seharusnya didukung dengan suatu pengawasan yang berkualitas guna menjamin pendistribusian dana yang merata pada semua sektor publik dan penggunaan yang ekonomis, efektif dan efisien. Pengelolaan keuangan pemerintah yang baik harus didukung audit sektor publik yang berkualitas, karena jika kualitas audit sektor publik rendah, akan memberikan kelonggaran terhadap lembaga pemerintah untuk melakukan penyimpangan penggunaan anggaran. Untuk mewujudkan pengawasan terhadap penyelenggaraan pemerintahan dan pengelolaan keuangan negara diperlukan kerjasama antara lembaga pemerintah yang berfungsi untuk melakukan pengawasan dan pemeriksaan terhadap instansi yang ada di lingkungan pemerintahan baik pusat maupun daerah. Dalam hal ini instansi yang mempunyai kewenangan adalah Badan Pemeriksa Keuangan yang bertindak sebagai auditor eksternal pemerintah dan Badan Pengawasan Keuangan dan Pembangunan (BPKP), Inspektorat Provinsi dan Daerah yang bertindak sebagai internal auditor yang lebih dikenal dengan sebutan Aparat Pengawasan Internal Pemerintah (APIP).

Inspektorat sebagai auditor internal pemerintah berperan dalam memberikan keyakinan yang memadai atas ketaatan, kehematan, efisiensi dan efektivitas pencapaian tujuan (assurance activities), memberikan masukan yang dapat memelihara dan meningkatkan kualitas penyelenggaraan tugas dan fungsi instansi pemerintah (consulting activities) serta memberikan peringatan dini dan meningkatkan efektivitas manajemen resiko (anticorruption activities).Sesuai dengan pasal 4 huruf g dan pasal 11 Peraturan Pemerintah Nomor 60 Tahun 2008 tentang Sistem Pengendalian Internal Pemerintah (SPIP), yang secara eksplisit ingin mewujudkan peran APIP yang efektif, yaitu dengan cara (a) memberikan keyakinan yang memadai atas ketaatan, kehematan, efisiensi, dan efektivitas pencapaian tujuan penyelenggaraan tugas dan fungsi instansi pemerintah; (b) memberikan peringatan dini dan meningkatkan efektivitas manajemen risiko dalam penyelenggaraan tugas dan fungsi instansi pemerintah; dan (c) memelihara dan meningkatkan kualitas tata kelola penyelenggaraan tugas dan fungsi instansi pemerintah. Hal tersebut diharapkan dapat memberikan nilai tambah dan meningkatkan kegiatan organisasi serta membantu organisasi mencapai tujuannya. Peran auditor internal pemerintah yang optimal akan memberikan dampak yaitu terwujudnya sistem pemerintahan yang baik, pengelolaan keuangan yang efektif dan efisien dan dapat melakukan deteksi dini terhadap penyelewengan serta terlaksananya kebijakan publik sesuai dengan peraturan perundang-undangan yang pada akhirnya meningkatkan kualitas pelayanan kepada masyarakat.

Dalam melaksanakan tugas sebagai auditor internal tuntutan akan profesionalisme dan objektivitas harus dipenuhi oleh seorang auditor walaupun pada kenyataannya banyak faktor yang dapat mempengaruhi pekerjaan auditor seperti faktor yang berasal dari individu menyangkut perannya sebagai pemeriksa dan sebagai konsultan setiap instansi pemerintah yang terkadang menimbulkan tekanan dalam diri auditor dan bisa meningkatkan stres. Faktor lain yang juga mempengaruhi pekerjaan auditor internal pemerintah adalah faktor organisasi dimana seorang auditor bekerja didalam suatu lingkungan organisasi yang didalamnya terdapat pimpinan, rekan kerja, dan pihak yang diaudit yang pada dasarnya memiliki perbedaan latar belakang, pola pikir, cara kerja dan kepentingannya masing-masing yang membutuhkan penyesuaian yang belum tentu dapat dipenuhi oleh auditor. Dalam kondisi seperti ini apabila seorang auditor tidak dapat menyesuaikan diri dengan keadaan yang ada maka ia tidak bisa melakukan pekerjaannya dengan baik sehingga timbul beban dalam diri auditor yang dapat menimbulkan stres. Dalam melaksanakan tugas auditor juga tidak lepas dari lingkungan kerja yang dalam hal ini adalah lingkungan fisik seperti pencahayaan, suhu ruangan, tingkat kebisingan dan kebersihan yang mempengaruhi auditor dalam bekerja. Bekerja dengan keadaan pencahayaan yang kurang baik, tingkat kebisingan yang tinggi dan keadaan lain yang tidak mendukung berdampak proses penyelesaian pekerjaan sehingga bisa meningkatkan stres.

Hasil studi sebelumnya mengenai pengaruh faktor pemicu stres terhadap stres kerja auditor di kantor akuntan publik di Yogyakarta oleh Setiadi (2015) menunjukkan bahwa variabel faktor individu (kelebihan beban kerja kualitatif dan kuantitatif, konflik peran, peran ambiguitas dan tekanan waktu) memiliki pengaruh positif terhadap stres kerja yang dialami auditor pada kantor akuntan publik yang ada di Yogyakarta. Sementara itu, variabel faktor organisasi maupun faktor 
lingkungan fisik tidak memiliki pengaruh terhadap stres kerja auditor. Penelitian ini dilakukan untuk mengetahui apakah hasil penelitian sebelumnya tentang pengaruh faktor individu, organisasi dan lingkungan kerja pada auditor independen sektor swasta dapat digeneralisasi kedalam organisasi pemerintah khususnya yang ada di Sulawesi Utara sehingga masalah dalam penelitian ini dapat dirumuskan sebagai berikut:

1. Apakah faktor individu berpengaruh dalam meningkatkan stres kerja auditor pemerintah di Sulawesi Utara?

2. Apakah faktor organisasi berpengaruh dalam meningkatkan stres kerja auditor pemerintah di Sulawesi Utara?

3. Apakah faktor lingkungan kerja berpengaruh dalam meningkatkan stres kerja auditor pemerintah di Sulawesi Utara?

Adapun penelitian ini bertujuan untuk membuktikan secara empiris pengaruh faktor individu, organisasi dan lingkungan kerja dalam meningkatkan stres kerja auditor pemerintah di Sulawesi Utara. Penelitian ini juga diharapkan akan bermanfaat sebagai bahan evaluasi mengenai cara kerja, lingkungan kerja dan proses kerja pada instansi pemerintah yang didalamnya auditor bekerja sehingga kinerja auditor pemerintah semakin baik.

\section{Tinjauan Pustaka \\ Teori Atribusi}

Teori atribusi diperkenalkan oleh Heider tahun 1958. Ia adalah salah satu ahli psikologi yang pertama kali mendefinisikan istilah atribusi. Heider (1958) mengemukakan dua pengertian tentang atribusi yaitu atribusi sebagai proses persepsi dan sebagai penilaian kausalitas. Atribusi sebagai proses persepsi merupakan inti dari proses persepsi manusia. Lebih jauh Heider berpendapat bahwa manusia terikat dalam proses psikologis yang menghubungkan pengalaman subyektif mereka dengan berbagai objek yang ada. kemudian, berbagai objek tersebut direkonstruksi secara kognitif agar menjadi sumber-sumber akibat dari pengalaman perseptual. Sebaliknya, ketika orang mencoba untuk membayangkan sebuah objek, maka mereka akan menghubungkan pengalaman tersebut ke dalam alam pikiran mereka. Sedangkan atribusi sebagai penilaian kausalitas adalah proses dimana orang merasakan dan membuat penilaian tentang orang lain yang menekankan pada penyebab orang berperilaku tertentu.

Teori Atribusi menurut Ivancevich et al (2014:98) menyatakan bahwa atribusi adalah sebuah upaya individu untuk menjelaskan alasan suatu kejadian. Teori atribusi berusaha menjelaskan mengapa perilaku didasarkan pada atribusi orang terhadap penyebab hingga suatu peristiwa terjadi. Teori atribusi memandang proses dimana individu menafsirkan peristiwa di sekitar mereka disebabkan (dikaitkan dengan) bagian yang relatif stabil dari lingkungan mereka. Menurut teori atribusi, atribusi adalah penyebab apa yang dirasakan dari suatu kejadian, bukan kejadian itu sendiri, yang mempengaruhi perilaku individu. Lebih khusus lagi, individu tertarik untuk menganalisis mengapa peristiwa tertentu terjadi, dan hasil analisis itu mempengaruhi perilaku mereka dimasa depan.

Menurut Robbins dan Judge (2017:104), teori atribusi mencoba menjelaskan cara-cara kita menilai orang dengan berbeda bergantung pada pengertian yang kita atribusikan pada sebuah perilaku. Itu menyatakan bahwa ketika kita mengamati perilaku seorang individu, maka kita sedang mencoba menentukan apakah itu disebabkan dari internal atau eksternal. Perilaku yang disebabkan internal adalah yang dipercaya pengamat berada dalam kendali perilaku pribadi dari individu sedangkan perilaku yang disebabkan eksternal adalah apa yang kita bayangkan dimana situasi memaksa individu untuk melakukannya.

Kemudian terdapat pula teori motivasi yang dikemukakan oleh Herzberg pada tahun 1960. Herzberg adalah seorang ahli psikolog klinis dan dianggap sebagai salah satu pemikir besar dalam bidang manajemen dan teori motivasi. Herzberg (1960) mengemukakan teori motivasi berdasar teori dua faktor yaitu faktor hygiene dan motivator. Herzberg membagi kebutuhan Maslow menjadi dua bagian yaitu kebutuhan tingkat rendah (fisik, rasa aman, dan sosial) dan kebutuhan tingkat tinggi (prestise dan aktualisasi diri) serta mengemukakan bahwa cara terbaik untuk memotivasi seseorang adalah dengan mengorganisasi pekerjaan sedemikian rupa sehingga memberikan tantangan dan pengakuan yang dibutuhkan semua orang untuk membantu memuaskan kebutuhan "tingkat yang lebih tinggi" terkait hal-hal seperti pencapaian dan pengakuan. Pekerjaan yang 
menantang memberikan sejenis pembangkit motivasi, sedangkan melakukan pekerjaan yang memuaskan kebutuhan "tingkat rendah" pekerja seperti bayaran dan kondisi kerja yang lebih baik hanya menjaga agar seseorang tidak merasa puas. Menurut Herzberg bila faktor "hygiene" (faktor diluar pekerjaan) seperti kondisi kerja, gaji, dan insentif sudah tidak memadai, karyawan menjadi tidak puas, namun apabila ditambahkan lebih banyak "hygiene" merupakan cara yang kurang baik dalam memotivasi seseorang karena mengandalkan insentif finansial secara eksklusif sangat beresiko.

Kepemimpinan sangat mempengaruhi sebuah kelompok menuju pencapaian sebuah visi atau tujuan yang ditetapkan. Organisasi memerlukan kepemimpinan yang kuat untuk efektivitas yang optimal. Para pemimpin yang kuat dapat digambarkan dengan sifat-sifat mereka yang kemudian melahirkan teori sifat. Namun kegagalan kegagalan dari studi-studi sifat mengarahkan para peneliti terhadap cara yang unik dari perilaku para pemimpin, dari kedua teori ini kemudian dikembangkan teori kontingensi oleh Fred Fiedler yang adalah seorang peneliti yang mempelajari kepribadian dan karakteristik pemimpin pada pertengahan tahun 1967. Teori kontingensi menyatakan bahwa kinerja kelompok yang efektif bergantung pada kecocokan yang tepat antara gaya pemimpin dan seberapa besar situasi memberikan kendali pada pemimpin.

Sebagian besar dari apa yang kita ketahui sekarang mengenai stres dapat ditemukan pada karya Dr. Hans Selye yaitu model sindrom adaptasi umum (general adaptation syndrome). Menurut model ini tiap individu mempunyai tingkat resistensi normal terhadap kejadian yang menimbulkan stres, beberapa diantaranya dapat mentoleransi stres dalam jumlah besar dan yang lainya lebih sedikit, tetapi semua mempunyai ambang batas dimana stres mulai mempengaruhi kita. Sindrom adaptasi umum dimulai ketika seseorang mulai menjumpai faktor pemicu stres (stressor) dimana pada tahap awal yang disebut "peringatan" seseorang merasa panik pada tingkat tertentu dan mulai bertanya-tanya bagaimana cara mengatasinya, pada situasi seperti ini seseorang dapat melawan atau menghindari. Tahap kedua adalah "resistensi" dimana seseorang dapat menolak pengaruh faktor pemicu stres dan tetap melanjutkan aktivitas dan pada akhirnya timbul rasa puas karena dapat mengatasi tekanan yang dapat memicu stres. Sebaliknya pada tahap yang ketiga yaitu "kelelahan" yang diakibatkan seseorang karena seseorang tidak dapat melawan faktor pemicu stres sehingga membuat seseorang benar-benar menyerah.

Moorhead dan Griffin (2013:175) mendefinisikan stres sebagai respon adaptif seseorang terhadap rangsangan yang menempatkan tuntutan psikologis atau fisik secara berlebihan kepadanya. Dari pengertian ini terdapat tiga komponen yaitu (1) gagasan adaptasi dimana biasanya individu dapat beradaptasi dengan keadaan yang menimbulkan stres dengan berbagai cara, (2) Rangsangan, perangsang ini biasanya disebut stressor yaitu segala sesuatu yang memicu stres, (3) stressor dapat bersifat psikologis atau fisik.

Menurut Robbins dan Judge (2017:429), stres merupakan kondisi dinamis yaitu individu berkonfrontasi dengan peluang, tuntutan, atau sumber daya yang terkait dengan apakah yang individu inginkan dan yang mana hasil yang dipandang menjadi tidak pasti dan penting. Ivancevich et al (2014:232), mendefinisikan stres sebagai respon adaptif yang dimoderasi oleh perbedaan individual yang merupakan konsekuensi dari tindakan, situasi, atau peristiwa yang memberikan tuntutan khusus pada seseorang. stres bisa dilihat sebagai stimulus (stressors) dan sebagai respon. Stres sebagai stimulus menganggap stres sebagai karakteristik atau peristiwa yang mungkin menghasilkan konsekuensi yang tidak beraturan sedangkan stres sebagai suatu respon merupakan konsekuensi dari interaksi antara stimulus lingkungan dengan respon individu.

Stres kerja adalah sesuatu kondisi ketegangan yang menciptakan adanya ketidakseimbangan fisik dan psikis yang mempengaruhi emosi, proses berpikir, dan kondisi seorang karyawan (Rivai, 2004:108). Menurut Handoko (2008:200), stres kerja adalah suatu kondisi ketegangan yang mempengaruhi proses berpikir, emosi, dan kondisi seseorang, hasilnya stres yang terlalu berlebihan dapat mengancam kemampuan seseorang untuk menghadapi lingkungan dan pada akhirnya akan mengganggu pelaksanaan tugas-tugasnya. Orang-orang yang mengalami stres menjadi nervous dan merasakan kekuatiran kronis sehingga mereka sering menjadi marah-marah, agresif, tidak dapat relaks, atau memperlihatkan sikap yang tidak kooperatif (Hasibuan, 2012:204).

Penelitian ini dilakukan untuk menganalisis pengaruh variabel independen yaitu faktor individu yang dijabarkan melalui indikator (konflik peran, ambiguitas peran, beban kerja, dan tekanan waktu), faktor organisasi yang dijabarkan melalui indikator (reward, partisipasi dalam 
pengambilan keputusan, dan gaya supervisor) dan faktor lingkungan kerja yang dijabarkan melalui indikator (cahaya, suara, suhu, sirkulasi udara, dan kebersihan) terhadap variabel dependen yaitu stres kerja auditor. Maka dapat digambarkan dalam model seperti berikut:

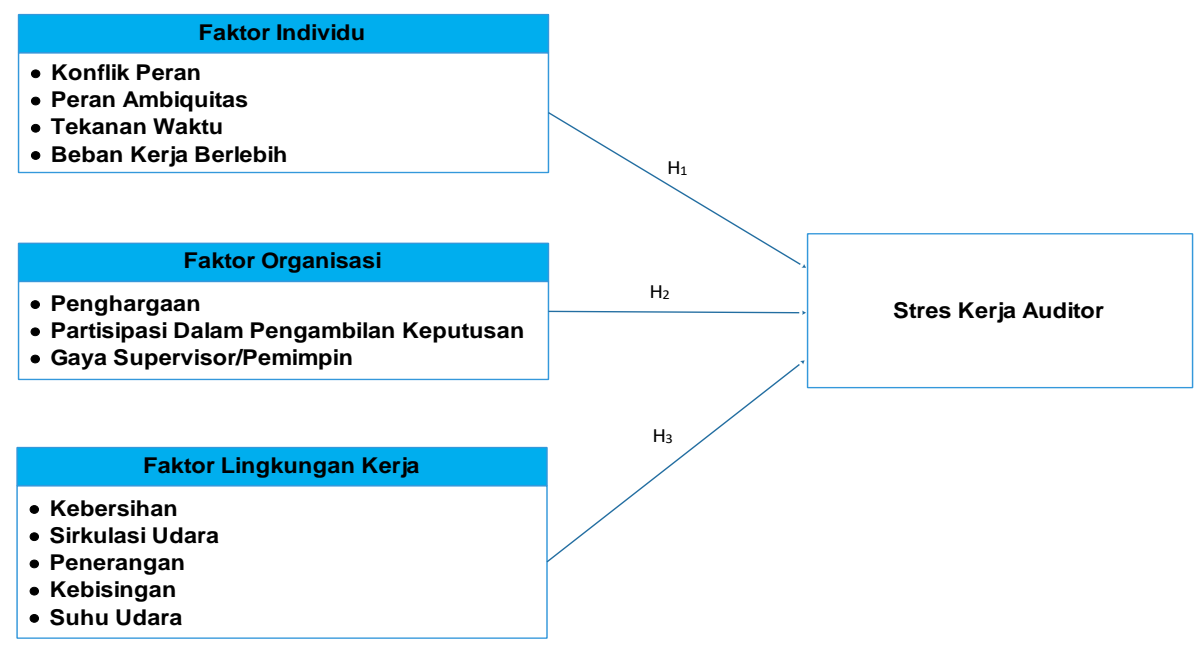

\section{Hipotesis Penelitian \\ Faktor individu terhadap stres kerja}

Menurut Moorhead dan Griffin (2013:180), tuntutan peran dapat menimbulkan stres kepada orang-orang dalam organisasi. Sebuah peran adalah serangkaian perilaku yang diharapkan sehubungan dengan posisi tertentu dalam sebuah kelompok atau organisasi. Orang-orang dalam suatu organisasi mengharapkan seseorang dengan peran tertentu untuk bertindak dengan cara tertentu, dengan adanya ekspektasi ini maka individu akan berusaha untuk mewujudkannya, namun kesalahan dapat terjadi dalam proses ini sehingga menghasilkan masalah yang memicu stres yang disebut role conflict dan role ambiguity.Dalam model stres kerja yang dikembangkan oleh Ivancevich dan Matteson, "Organizational Stressor and Heart Disease", (dalam Kinicki dan Fugate, 2016:581) penyebab stres antara lain meliputi: level individual, level kelompok, level organisasional, dan level ekstra organisasional. Stressor level individual yaitu yang secara langsung dikaitkan dengan tugas pekerjaan seseorang (person-job interface) seperti role overload, role conflict, role ambiquity dan responsibility for other people. Berdasarkan uraian diatas dapat diajukan hipotesis sebagai berikut:

\section{$\mathrm{H}_{1}$ : Faktor individu berpengaruh positif terhadap stres kerja auditor}

Menurut Ivancevich et al (2014:235), stres kerja dipengaruhi oleh reward, gaya kepemimpinan, struktur organisasi dan partisipasi dalam pengambilan keputusan. Suatu kelompok atau organisasi yang tidak memberikan partisipasi kepada anggota atau karyawan akan menjadi sumber frustasi bagi anggota atau karyawan tersebut. Buruknya hubungan antar personal dalam sebuah kelompok seperti kurangnya kepercayaan, rendahnya dukungan, bisa menjadi sumber stres. Vroom dan Yetton dalam model pemimpin partisipasi menekankan pentingnya partisipasi bawahan dalam pengambilan keputusan yang mana hal ini akan meningkatkan kepuasan dan produktivitas tetapi sebaliknya apabila keputusan hanya dilakukan secara sepihak akan menimbulkan rasa tidak dihargai yang kemudian dalam jangka panjang akan berpotensi menimbulkan stres. Menurut Luthans (2011:282), penyebab terjadinya stres yang bersifat organisasi salah satunya adalah struktur dalam organisasi yang terbentuk melalui desain organisasi yang ada, misalnya melalui formalisasi, konflik dalam hubungan antar karyawan, spesialisasi, serta lingkungan yang kurang mendukung. Berdasarkan uraian diatas maka dapat diajukan hipotesis sebagai berikut:

\section{$\mathbf{H}_{2}$ : Faktor organisasi berpengaruh positif terhadap stres kerja auditor}


Menurut Sedarmayanti (2009:22), lingkungan kerja fisik adalah semua yang terdapat disekitar tempat kerja yang dapat mempengaruhi pegawai baik secara langsung maupun tidak langsung. Kondisi lingkungan kerja dikatakan baik atau sesuai apabila manusia dapat melaksanakan kegiatan secara optimal, sehat, aman, dan nyaman. Kesesuaian lingkungan kerja dapat dilihat akibatnya dalam jangka waktu yang lama lebih jauh lagi lingkungan-lingkungan kerja yang kurang baik dapat menuntut tenaga kerja dan waktu yang lebih banyak dan tidak mendukung diperolehnya rancangan sistem kerja yang efisien. Menurut Susanti (2016), Tuntutan fisik dari suatu pekerjaan adalah persyaratan fisik pada pekerjanya. Tuntutan ini adalah fungsi dari karakteristik fisik dari situasi dan tugas fisik yang dibutuhkan dalam pekerjaan seperti temperatur, cahaya, kebisingan dan kebersihan. Bekerja dengan temperaturkantor yang tidak didinginkan, adanya suara bising disekitar, pencahayaan yang kurang serta tingkat kebersihan yang kurang akan menyebabkan stres. Tingkat stres seorang auditor pemerintah bisa saja dipengaruhi oleh faktor lingkungan kerja seperti sirkulasi udara, suhu ruangan, tingkat pencahayaan dan kebisingan. Apabila faktor lingkungan kerja dapat diterima oleh auditor maka auditor tidak akan mengalami stres sebaliknya apabila lingkungan fisik kurang nyaman maka ketegangan akan terasa kemudian membuat suasana kerja tidak nyaman dan meningkatkan stres. Berdasarkan uraian diatas dapat diajukan hipotesis penelitian sebagai berikut:

\section{$H_{3}$ : Faktor lingkungan kerja berpengaruh positif terhadap stres kerja auditor}

\section{Metode Penelitian Jenis dan Sumber Data}

Penelitian ini adalah penelitian kuantitatif yang menggunakan data kualitatif dengan sumber data primer, dalam hal ini peneliti menggunakan kuisioner yang dibagikan kepada auditor pemerintah yang ada di Sulawesi Utara dengan tujuan untuk menguji pengaruh faktor individu $\left(\mathrm{X}_{1}\right)$, faktor organisasi $\left(\mathrm{X}_{2}\right)$ dan faktor lingkungan kerja $\left(\mathrm{X}_{3}\right)$ terhadap stres kerja auditor $(\mathrm{Y})$.

\section{Populasi, Sampel dan Teknik PengambilanSampel}

Populasi penelitian ini adalah auditor pemerintah yang ada di Sulawesi Utara, sedangkan yang menjadi sampel adalah inspektorat yang ada di wilayah Sulawesi Utara. Jumlah partisipan yang direncanakan dalam penelitian ini berjumlah 50 sampai 100 orang. Teknik pengambilan sampel penelitian menggunakan metode purposive sampling dimana peneliti mengambil sampel sesuai dengan kriteria yang dikehendaki oleh peneliti (Trochim et al, 2014:87).

\section{Teknik Pengumpulan Data}

Teknik pengumpulan data yang digunakan dalam penelitian ini adalah dengan menggunakan kuisioner yaitu teknik pengumpulan data yang dilakukan dengan cara memberi seperangkat pertanyaan atau pernyataan tertulis kepada responden untuk dijawabnya, (Sugiyono, 2015:230). Adapun kuisioner yang akan dibagikan terbagi menjadi 2 bagian, yang pertama mengenai identitas responden dan yang kedua berisi pertanyaan yang berhubungan dengan variabel penelitian. Untuk mengukur nilai variabel yang diteliti digunakan skala Likert dengan gradasi dari "sangat tidak setuju" sampai "sangat setuju".

\section{Hasil Penelitian}

Penelitian ini menggunakan data primer dengan instrumen kuisioner. Responden penelitian ini adalah sejumlah auditor internal yang ada di 7 (tujuh) kantor Inspektorat wilayah Provinsi Sulawesi Utara, yaitu Inspektorat Provinsi Sulawesi Utara, Inspektorat Kota Manado, Inspektorat Kota Bitung, Inspektorat Kota Tomohon, Inspektorat Kabupaten Minahasa, Inspektorat Kabupaten Minahasa Utara, dan Inspektorat Kabupaten Sangihe. Jumlah kuisioner yang disebar sebanyak 100 buah. Uraian rincian penyebaran kuisioner disajikan pada Tabel 1. 
Tabel 1. Data Penyebaran Kuisioner

\begin{tabular}{|c|l|c|c|c|c|}
\hline No & \multicolumn{1}{|c|}{ Instansi } & $\begin{array}{c}\text { Kuisioner } \\
\text { Disebar }\end{array}$ & $\begin{array}{c}\text { Kuisioner } \\
\text { Kembali }\end{array}$ & $\begin{array}{c}\text { Tidak } \\
\text { Kembali }\end{array}$ & $\begin{array}{c}\text { Rata-rata } \\
\text { Respon }\end{array}$ \\
\hline 1 & $\begin{array}{l}\text { Inspektorat Provinsi } \\
\text { Sulawesi Utara }\end{array}$ & 20 & 17 & 3 & $85.0 \%$ \\
\hline 2 & Inspektorat Kota Manado & 10 & 10 & 0 & $100 \%$ \\
\hline 3 & Inspektorat Kota Bitung & 10 & 10 & 0 & $100 \%$ \\
\hline 4 & Inspektorat Kota Tomohon & 15 & 10 & 5 & $66.7 \%$ \\
\hline 5 & $\begin{array}{l}\text { Inspektorat Kabupaten } \\
\text { Minahasa }\end{array}$ & 25 & 24 & 1 & $96.0 \%$ \\
\hline 6 & $\begin{array}{l}\text { Inspektorat Kabupaten } \\
\text { Minahasa Utara }\end{array}$ & 10 & 8 & 2 & $80.0 \%$ \\
\hline 7 & $\begin{array}{l}\text { Inspektorat Kabupaten } \\
\text { Sangihe }\end{array}$ & 10 & 8 & 2 & $80.0 \%$ \\
\hline \multicolumn{2}{|c|}{ Total } & $\mathbf{1 0 0}$ & $\mathbf{8 7}$ & $\mathbf{1 3}$ & $\mathbf{8 6 , 8 1 \%}$ \\
\hline
\end{tabular}

Sumber: Data olahan

Jumlah sebaran kuisioner terbanyak di Kantor Inspektorat Kabupaten Minahasa sebanyak 25 buah. Jumlah tersedikit sebanyak 10 buah di Kantor Inspektorat Manado, Bitung, Minahasa Utara dan Sangihe. Jumlah kuisioner yang kembali sebanyak 87 buah dan tidak kembali sebanyak 13 buah. Dari 13 buah kuisioner yang tidak kembali, terbanyak ada pada Kantor Inspektorat Tomohon sebanyak 5 buah dan yang sedikit pada Kantor Inspektorat Minahasa sebanyak 1 buah.

Sebelum dilakukan pengujian hipotesis, peneliti melakukan analisis statistik deskriptif untuk menggambarkan kondisi sebaran data. Hasil pengujian statistik deskriptif disajikan pada Tabel 2 berikut.

Tabel 2. Statistik Deskriptif Variabel

\begin{tabular}{|l|c|c|c|c|}
\hline \multicolumn{1}{|c|}{ Variabel Penelitian } & $\begin{array}{c}\text { Jumlah } \\
\text { Sampel }\end{array}$ & Mean & $\begin{array}{c}\text { Standar } \\
\text { Deviasi }\end{array}$ & Variance \\
\hline Faktor Individu & 87 & 27.7126 & 4.38525 & 19.23 \\
\hline Faktor Organisasi & 87 & 13.6897 & 3.13758 & 9.844 \\
\hline Faktor Lingkungan Kerja & 87 & 32.1609 & 3.28801 & 10.811 \\
\hline Stres Kerja Auditor & 87 & 36.5517 & 7.56177 & 57.18 \\
\hline Valid N (listwise) & 87 & & & \\
\hline
\end{tabular}

Sumber: Data olahan

Hasil pengujian statistik deskriptif pada tabel 2 menunjukan bahwa variabel faktor individu memiliki nilai mean sebesar 27,71 dan nilai standar deviasi sebesar 4,38. Variabel faktor organisasi memiliki nilai mean 13,68 dan standar deviasi 3,13. Variabel faktor lingkungan kerja memiliki nilai mean 32,16 dan standar deviasi 3,28. Variabel stres kerja auditor memiliki nilai mean 36,55 dan standar deviasi 7,56. Karena nilai standar deviasi yang lebih kecil daripada nilai rata-rata (mean) mengandung arti bahwa sebaran data semua variabel tidak jauh berbeda.

Selain pengujian statistik deskriptif, penelitian ini juga melakukan pengujian validitas dan reliabilitas. Pengujian validitas menggunakan analisis faktor dengan indikator nilai Kaiser-Meyer Olkin $(K M O)$ yang lebih besar dari 0,5 dan nilai Bartllet's Test of Sphericity lebih kecil 0,05. Sementara itu, uji reliabilitas menggunakan indikator nilai Cronbach alpha $>0,60$ atas sejumlah pertanyaan pada setiap indikator variabel (Sekaran, 2009:289).

Nilai Kaiser Meyer Olkin-Measure of Sampling Adequacy (KMO-MSA) yang dihasilkan untuk variabel faktor individu sebesar 0,738 , variabel faktor organisasi sebesar 0,765, variabel lingkungan kerja sebesar 0,755 dan variabel stres kerja auditor sebesar 0,849. Beberapa hasil tersebut berarti bahwa butir pertanyaan dalam kuisioner ini valid.

Hasil uji reliabilitas menunjukan bahwa nilai Cronbach alpha variabel faktor individu sebesar 0,723 , variabel faktor organisasi sebesar 0,872 , variabel faktor lingkungan kerja sebesar 0,898 dan variabel stres kerja sebesar 0,902. Beberapa nilai ini menunjukan bahwa kuisioner penelitian ini reliabel. 


\section{Hasil Pengujian Hipotesis}

Hasil pengujian hipotesis penelitian ini dengan menggunakan regresi linear berganda disajikan pada Tabel 3.

Tabel 3. Hasil uji regresi linear berganda

\begin{tabular}{|c|c|c|c|c|c|}
\hline \multirow[b]{2}{*}{ Model } & \multicolumn{2}{|c|}{ F-Test } & \multicolumn{3}{|c|}{ t-Test } \\
\hline & $\mathbf{F}$ & Sig & $\beta$ & $t$ & Sig. \\
\hline (Constant) & & & $-10,545$ & $-0,249$ & 0,845 \\
\hline Faktor Individu & \multirow{3}{*}{91.996} & \multirow{3}{*}{$0.076^{\mathrm{b}}$} & $-0,567$ & $-0,692$ & 0,615 \\
\hline Faktor Organisasi & & & 2,934 & 3,895 & 0,160 \\
\hline Faktor Lingkungan Kerja & & & 0,459 & 1,739 & 0,332 \\
\hline
\end{tabular}

Hasil uji pada Tabel 3 menunjukan bahwa nilai koefisien variabel faktor individu sebesar 0,567 dengan nilai $t$-test sebesar -0,692 dan tingkat probabilitas signifikansi sebesar 0,615. Hasil ini menunjukkan bahwa secara statistik variabel faktor individu tidak berpengaruh secara signifikan. Hasil ini berarti hipotesis 1 (pertama) penelitian ini tidak terdukung.

Hasil di dalam Tabel 3 menunjukkan bahwa nilai koefisien variabel faktor organisasi adalah sebesar 2,934 dengan nilai $t$-test sebesar 3,895 dan tingkat probabilitas signifikansi sebesar 0,160. Hasil ini menunjukkan bahwa secara statistik variabel faktor organisasi tidak berpengaruh secara signifikan. Hasil ini berarti hipotesis 2 (kedua) penelitian ini tidak terdukung.

Sementara itu, Tabel 3 juga menunjukkan bahwa nilai koefisien variabel faktor lingkungan kerja adalah sebesar 0,459 dengan nilai $t$-test sebesar 1,739 dan tingkat probabilitas signifikansi sebesar 0,332. Hasil ini menunjukkan bahwa secara statistik variabel faktor lingkungan kerja tidak berpengaruh secara signifikan. Hasil ini berarti juga bahwa hipotesis 3 (ketiga) penelitian ini tidak terdukung.

Terkait dengan nilai-nilai koefisien yang dihasilkan untuk ketiga variabel penelitian ini dengan menggunakan regresi linear berganda dinyatakan pada persamaan sebagai berikut:

$$
\begin{array}{ll}
\mathrm{Y}=-10,545-0,567 \mathrm{X}_{1}+2,934 \mathrm{X}_{2}+0,459 \mathrm{X}_{3}+\varepsilon \\
\text { Keterangan } & \mathrm{Y}=\text { Stres kerja auditor } \\
& \mathrm{X}_{1}=\text { Faktor individu } \\
\mathrm{X}_{2}=\text { Faktor organisasi } \\
\mathrm{X}_{3}=\text { Faktor lingkungan kerja } \\
\varepsilon=\text { Error }
\end{array}
$$

Hasil uji pada Tabel 3 juga menunjukan nilai F-hitung sebesar 91.996 dengan nilai probabilitas signifikansi sebesar 0,076. Hasil ini menunjukkan bahwa pada level $10 \%$ model persamaan yang digunakan signifikan. Artinya, model persamaan dengan menggunakan ketiga variabel tersebut cukup fit.

Sementara itu, nilai koefisien determinasi $\left(R^{2}\right)$ sebesar 0,568. Hasil ini berarti bahwa perubahan variabel stres kerja sebesar $56,8 \%$ dapat disebabkan oleh ketiga variabel penelitian ini yaitu, faktor individu, faktor organisasi dan faktor lingkungan kerja sedangkan sisanya disebabkan oleh variabel lain.

\section{Pembahasan}

\section{Pengaruh faktor individu terhadap stres kerja auditor}

Berdasarkan penelitian yang telah dilakukan, ditemukan pertama, dalam penelitian ini diketahui bahwa stres kerja tidak dipengaruhi oleh faktor individu yang dijabarkan melalui indikator: (1) konflik peran, walaupun konflik peran dapat terjadi karena peran ganda auditor selaku pemeriksa dalam peran sebagai pengawas dan auditor sebagai konsultan dalam perannya memberikan jasa konsultasi namun dengan penerapan standar audit pemerintah tentang independensi dan objektivitas dalam menjalankan tugas membuat auditor tidak kesulitan untuk menyesuaikan perannya dan bertanggung jawab dalam melaksanakan pekerjaannya; (2) ambiguitas peran, ambiguitas perandapat terjadi ketika dalam penugasan audit tugas-tugas auditor tidak 
didefinisikansecara jelas sehingga auditor merasa bingung dalam mempertanggungjawabkan pekerjaan sehingga meningkatkan stres. Hal ini tidak terjadi pada auditor pemerintah karena didalam standar audit internal pemerintah telah diatur mengenai standar pelaksanaan pekerjaan dimana seorang auditor harus membuat rencana audit, menetapkan sasaran, ruang lingkup, metodologi dan alokasi sumber daya dan didalam Permendagri No.35 Tahun 2018 tentang kebijakan pengawasanpenyelenggaraan pemerintah daerah sudah diatur dengan jelas mengenai uraian kegiatan pengawasan sehingga apabila ini diterapkan dalam melaksanakan tugas maka auditor akan memahami dengan jelas tugas dan tanggungjawabnya; (3) tekanan waktu, sebelum melaksanakan tugas pemeriksaan, auditor internal pemerintah sesuai dengan standar yang ada sudah harus melakukan perencanaan kemudian meminta persetujuan pimpinan sehingga dalam penugasan sangat kecil kemungkinan adanya tekanan waktu untuk mempercepat pemeriksaan hal ini sangat berbeda dengan audit pada sektor swasta dimana apabila atas desakan kebutuhan akan laporan hasil audit, perusahaan dapat meminta auditor untuk mempercepat pekerjaan sehingga auditor harus kerja ekstra dan bisa menyebabkan stres;(4) beban kerja berlebih, pada instansi pemerintah sangat kecil kemungkinan akan adanya kelebihan beban kerja yang diberikan kepada auditor hal ini karena sesuai dengan Permendagri No. 64 Tahun 2007 pasal 16 bahwa jumlah tenaga fungsional ditentukan sesuai dengan kebutuhan dan beban kerja sehingga auditor yang bekerja selalu disesuaikan dengan tingkat kebutuhan sehingga pembagian pekerjaan auditor menjadi lebih merata.

Hasil penelitian ini tidak sejalan dengan penelitian sebelumnya oleh Setiawan (2009) yang dilakukan terhadap internal auditor Bank Negara Indonesia yang menyatakan bahwa kelebihan beban kerja, tekanan waktu, dan lingkup pekerjaan menjadi pemicu stres pada auditor internal Bank Negara Indonesia. Temuan ini mengkonfirmasi jawaban responden terhadap pertanyaan menyangkut konflik peran, peran ambiguitas, tekanan waktu dan beban kerja yang berlebih dimana responden merasa bahwa faktor-faktor tersebut tidak membuat auditor internal pemerintah merasa stres dalam melakukan pekerjaan. Ini sesuai dengan teori atribusi bahwa perilaku setiap orang bisa berbeda dalam situasi yang sama dan hal itu sangat dipengaruhi oleh faktor internal dan eksternal.

\section{Pengaruh faktor organisasi terhadap stres kerja auditor}

Kedua, hasil penelitian ini menunjukan bahwa stres kerja tidak dipengaruhi faktor organisasi yang dijabarkan melalui indikator: (1) penghargaan, penghargaan selalu menjadi motivasi saat melakukan pekerjaan apakah penghargaan dalam bentuk pujian, insentif, upah atau promosi jabatan. Pada instansi pemerintah insentif sudah diberikan sesuai dengan golongan dan bagi auditor juga diberikan kesempatan untuk terus mengikuti diklat fungsional auditor internal pemerintah yang secara tidak langsung juga merupakan bentuk penghargaan sehingga bagi auditor pemerintah reward tidak menjadi faktor yang bisa membuatnya mereka bekerja sampai batas tertentu yang bisa membuatnya mengalami stres; (2) partisipasi dalam pengambilan keputusan tidak mempengaruhi stres kerja pada auditor pemerintah karena sesuai standar audit aparat pengawasan internal pemerintah mengharuskan adanya komunikasi yang intensif antara auditor dengan pimpinan maupun antara sesama auditor dan auditor selalu dilibatkan dalam pengambilan keputusan (3) gaya kepemimpinan tidak mempengaruhi stres kerja auditor karena dilingkungan kantor inspektorat pemerintah dimana struktur organisasi mencerminkan pembagian tugas dan wewenang serta garis koordinasi yang jelas memungkinkan setiap pegawai mengerti akan tugas dan tanggungjawabnya sehingga yang menjadi tolak ukur dalam bekerja adalah standar yang telah ditetapkan dan pada umumnya tipe pemimpin yang ada di inspektorat selalu membimbing dan memotivasi para bawahan menuju tujuan yang telah ditetapkan dengan menjelaskan peran dan tugas yang dibutuhkan.

Hasil penelitian tidak sejalan dengan penelitian yang dilakukan oleh Larson (2004) pada auditor internal yang terdaftar sebagai American Institute of Certified Public Accountant yang ada di Amerika dimana faktor lingkungan organisasi dan lingkungan kerja menjadi sumber stres utama dibandingkan dengan faktor individu. Hasil penelitian ini sesuai dengan teori kontingensi model kepemimpinan Vroom dan Yetton yang menyatakan bahwa pemimpin yang mampu membuat keputusan dengan baik adalah pemimpin yang melibatkan bawahannya dalam pengambilan keputusan. 


\section{Pengaruh faktor lingkungan kerja terhadap stres auditor}

Ketiga, penelitian ini juga menunjukan bahwa stres kerja tidak dipengaruhi oleh faktor lingkungan kerja yang dijabarkan melalui indikator (1) pencahayaan, pencahayaan yang baik atau kurang baik tidak membuat auditor menjadi stres karena auditor sudah bisa menyesuaikan diri dan terbiasa dengan keadaan yang ada; (2) kebisingan, tingkat kebisingan yang tinggi juga tidak membuat auditor menjadi stres dalam bekerja karena auditor merasa sudah terbiasa bekerja dengan lingkungan yang bising (3) kebersihan, tingkat kebersihan sudah tidak menjadi faktor yang menyebabkan auditor menjadi stres dalam melakukan pekerjaan karena kebersihan kantor pemerintah sudah sangat diperhatikan; (4) sirkulasi dan suhu udara tidak mempengaruhi tingkat stres auditor dalam melaksanakan tugasnya karena auditor sudah bisa beradaptasi dan terbiasa dengan lingkungan tempat bekerja. Hasil penelitian ini tidak sejalan dengan penelitian yang dilakukan oleh Larson (2004) pada auditor internal yang terdaftar sebagai American Institute of Certified Public Accountant yang ada di Amerika dimana faktor lingkungan kerja menjadi salah satu sumber stres utama. Penelitian ini sesuai dengan model sindrom adaptasi umum (general adaptation syndrome) yang menyatakan bahwa tiap individu mempunyai tingkat resistensi normal terhadap kejadian yang menimbulkan stres, beberapa diantaranya dapat mentoleransi stres dalam jumlah besar dan yang lainya lebih sedikit tetapi semua mempunyai ambang batas toleransi terhadap stres.

\section{Kesimpulan}

Dari hasil penelitian dapat disimpulkan bahwa:

1. Menurut persepsi para auditor internal pemerintah di lingkungan kantor inspektorat wilayah Provinsi Sulawesi Utara, faktor individu tidak memberikan dampak pada terjadinya peningkatan stres kerja.

2. Menurut persepsi para auditor internal pemerintah di lingkungan kantor inspektorat wilayah Provinsi Sulawesi Utara, faktor organisasi tidak memberikan dampak pada terjadinya peningkatan stres kerja.

3. Menurut persepsi para auditor internal pemerintah di lingkungan kantor inspektorat wilayah Provinsi Sulawesi Utara, faktor lingkungan kerja tidak memberikan dampak pada terjadinya peningkatan stres kerja.

\section{Saran}

Berdasarkan hasil penelitian maka saran yang dapat penulis berikan adalah

1. Standar pelaksanaan pekerjaan yang sudah jelas mengatur mengenai tugas dan tanggung jawab auditor internal pemerintah seharusnya menjadikan hasil kerja auditor internal pemerintah semakin baik dalam melaksanakan fungsi pemeriksaan, pengawasan, reviu, evaluasi dan pemberian jasa konsultasi.

2. Lingkungan kerja yang semakin diperhatikan oleh pemerintah diharapkan menjadikan auditor semakin baik dalam bekerja sehingga fungsi pengawasan terhadap penyelenggaraan pemerintahan di daerah tetap berjalan sebagaimana mestinya.

\section{Daftar Pustaka}

Handoko, H. (2008). Manajemen Personalia \& Sumberdaya Manusia.Edisi Kedua. Yogyakarta: BPFE UGM

Hasibuan, Malayu.(2012). Manajemen Sumber Daya Manusia. Edisi Revisi. Jakarta: Bumi Aksara

Ivancevich, J.M., Konopaske, R. \& Matteson M.T. (2014). Organizational Behavior \& Management. Tenth Edition. McGraw Hill

Kinicki, Angelo \& Fugate, Mel. (2016). Organizational Behavior A Practical, Problem Solving Approach. McGraw Hill

Larson, Lee Linda. (2004). Internal Auditors and Journal, Vol. 19 Iss 9 pp. 1119 - 1130

Luthans, Fred. (2011). Organizational BehaviorAn Evidence-Based Approach. Twelfth Edition. McGraw Hill

Moorhead, \& Griffin. (2013). Perilaku Organisasi, Manajemen Sumber Daya Manusia dan Organisasi. Jakarta: Salemba Empat. 
Peraturan Pemerintah Republik Indonesia No. 60 Tahun 2008 Tentang Sistem Pengendalian Intern Pemerintah. 28 Agustus 2008. Lembaran Negara Republik Indonesia Tahun 2008.

Peraturan Menteri Dalam Negeri No. 35 Tahun 2018 Tentang Kebijakan Pengawasan Penyelenggaraan Pemerintah Daerah Tahun 2019.

Rivai.(2004). Manajemen Sumber Daya Manusia Untuk Perusahaan: Dari Teori Ke Praktik.Jakarta: Raja Grafindo Persada.

Robbins, S.P. \& Timothy A.J. (2017). Perilaku Organisasi.Jakarta: Salemba Empat.

Sugiyono. (2015). Metode Penelitian \& Pengembangan. Bandung: Alfabeta.

Susanti. (2016). Faktor Penyebab Kelelahan dan Stres Kerja Terhadap Personel Air Traffic Controller di Bandar Udara X. Warta Ardhia Volume 42: 123-138.

Sedarmayanti. (2009). Sumber Daya Manusia Dan Produktivitas Kerja. Mandar Maju.

Sekaran, Uma \& Bougie, Rouke. (2009). Research Methods for Business A Skill Building Approach Fifth Edition. Wiley

Setiadi, Berry. (2015). Analisis Faktor-Faktor Pemicu Stres (Stressors) Terhadap Stres Kerja Auditor di Kantor Akuntan Publik di Kota Yogyakarta. Tesis. Yogyakarta: Universitas Gadjah Mada.

Setiawan. (2009). Analisis faktor-faktor pemicu stress (stressors)terhadap stress kerja internal auditor PT. Bank Negara Indonesia Persero. Tbk. Jurnal Ekonomi dan Bisnis Universitas Diponegoro.

Trochim, M. William, Donnelly, James P. \& Arora, Kanika. (2014). Research Methods, The Essential Knowledge Base. Cengage Learning. 